\title{
After West Virginia: The Fate of Expert Witness Fee Shifting in Patent Litigation
}

\author{
Monique Michal†
}

As legal disputes have become more complex, expert witnesses have played an increasingly prominent role in many areas of litigation. Parties to patent infringement cases in particular rely heavily on experts to resolve the difficult technical issues inherent in these disputes. Patent cases often involve not only advanced technology, but complicated damage calculations as well. Typically, the resolution of patent disputes requires that experts in the sciences, statistics and economics assist in the preparation of litigation and testify at trial. Particularly when determining damages, "in almost every case, expert opinions will be necessary." 1 Expert witnesses frequently charge several hundred dollars per hour. ${ }^{2}$ If experts are involved in both preparation and trial, a party's expert witness expenses may total tens or even hundreds of thousands of dollars. ${ }^{3}$ Consequently, prevailing parties often seek to recover these costs from their opponents as an element of their damage awards.

While Congress has generally provided for the recovery of expert witness fees in litigation under the Fees Act, ${ }^{4}$ it has limited the amount recoverable to $\$ 40$ for each day's attendance in court. ${ }^{5}$ Parties to patent infringement suits have therefore relied on the Patent Act's attorney fee shifting provision ${ }^{6}$ to recover their full expert witness expenses. Section 285 of the Act allows prevailing parties to recover "reasonable attorney fees" in "exceptional

$\dagger$ B.S. 1990, The University of California, Berkeley; J.D. Candidate 1993, The University of Chicago.

${ }^{1}$ Ned L. Conley, An Economic Approach to Patent Damages, 15 AIPLA Q J 354, 386 (1987) (expert testimony necessary to establish reasonable patent royalties).

2 Jean R. Sternlight, The Supreme Court's Denial of Reasonable Attorney's Fees to Prevailing Civil Rights Plaintiffs, 17 NYU Rev L \& Soc Change 535, 571 (1989/90).

${ }^{3}$ See, for example, Beckman Instruments, Inc. $v$ LKB Produkter AB, 892 F2d 1547 (Fed Cir 1989) (plaintiff claimed expenses of $\$ 409,406.10$ in compensation for experts and consultants); Mathis $v$ Spears, 857 F2d 749 (Fed Cir 1988) (affirming award of $\$ 45,000$ in expert witness fees); Lam, Inc. $v$ Johns-Manville Corp., 718 F2d 1056 (Fed Cir 1983) (affirming award of $\$ 29,533.46$ in fees for professional consultants).

- 28 USC \$ 1920(3) (1988).

- 28 USC \& 1821(b) (1988 \& Supp II 1990).

- 35 USC $\$ 285$ (1988). 
cases." The "exceptional cases" requirement limits these awards to cases where the court finds that the losing party has acted in bad faith. ${ }^{8}$

When construing attorney fee shifting statutes that do not expressly provide for expert fee recovery, federal district courts have split over the issue of whether the Fees Act limits the amount of expert witness fees recoverable. ${ }^{9}$ However, in Mathis $v$ Spears, ${ }^{10}$ the Court of Appeals for the Federal Circuit, which hears all appeals of patent cases, held that although a statute authorizing attorney fees without addressing expert witness fees will not ordinarily authorize expert fees, a district court could award full expert witness fees under $\S 285$ in patent cases involving "egregious abuse of the judicial process" by exercising its "discretion and inherent equity power."11 The Federal Circuit found that the Patent Act's attorney fee shifting provision codified the "bad faith" equitable discretion traditionally enjoyed by the district courts. ${ }^{12}$ This equity power allows the courts to award litigation expenses, including expert witness fees, in cases involving bad faith despite the absence of express statutory authorization. ${ }^{13}$ Mathis typified several Federal Circuit cases awarding expert witness fees under $\S 285 .{ }^{14}$

3 Id.

${ }^{8}$ Mathis, 857 F2d at 758.

- Opinions in support of such awards include Greenspan v Automobile Club of Michigan, 536 F Supp 411 (E D Mich 1982) (awarding fees of experts used in trial preparation under the attorney fee shifting provision of the Civil Rights Act of 1964); PPG Industries, Inc. v Celanese Polymer Specialties Co., 658 F Supp 555 (W D Ky 1987), rev'd on other grounds, 840 F2d 1565 (Fed Cir 1988) (awarding expert witness fees under the attorney fee shifting provision of the Patent Act); Codex Corp. v Milgo Electronic Corp., 541 F Supp 1198 (D Mass 1982) (awarding reasonable expenses and disbursements under the Patent Act's attorney fee shifting provision). Cases in which such awards were denied include Leroy $v$ City of Houston, 831 F2d 576 (5th Cir 1987) (because the Voting Rights Act does not specifically allow recovery of witness fees, the district court erred in awarding such costs in excess of the standard per diem amount); Glenn v General Motors Corp., 841 F2d 1567 (11th Cir 1988) (although the Equal Pay Act shifts to a losing defendant the burden of paying plaintiff's attorney fees, the statute does not shift witness fees in excess of the amount allowed by $\S 1821$ because it does not refer explicitly to witness fees); Northcross $v$ Memphis Board of Education, 611 F2d 624 (6th Cir 1979) (not allowing expert witness fees to be counted as part of a "reasonable attorney fee" under the Civil Rights Act and allowing their recovery only pursuant to 28 USC $\$ 1920$ ).

10 857 F2d 749 (Fed Cir 1988).

11 Id at 758-59.

12 Id at 758.

${ }^{13}$ Id at 757-58.

${ }^{14}$ See Beckman Instruments, 892 F2d at 1554 (remanding for an award of expert witness fees consistent with the decision); Rohm \& Haas Co. $v$ Crystal Chemical Co., 736 F2d 688, 693 (Fed $\mathrm{Cir}$ 1984) (recognizing the practice of awarding expert witness fees under $\S 285$, though not enforcing it); Lam, 718 F2d at 1069 (holding that $\$ 285$ permits the prevailing party to recover disbursements that were necessary for the case); Central Soya Co., 
This Federal Circuit practice has now been called into question. In 1991, the Supreme Court considered whether attorney fee shifting statutes provide sufficient authority to shift expert witness fees. In West Virginia University Hospitals, Inc. $v$ Casey, ${ }^{15}$ the plaintiff, who had prevailed in a civil rights action, attempted to recover expert witness fees under the Civil Rights Attorney's Fees Awards Act of $1976 .^{16}$ The Court held that expert witness fees could not be shifted as an element of a reasonable attorney's fee. ${ }^{17}$ Although the Court ruled specifically on the attorney fee shifting provision of the Civil Rights Act, the broad language of West Virginia arguably extends to all attorney fee shifting provisions that fail to provide expressly for expert witness fee awards.

Because the Federal Circuit has repeatedly awarded expert fees along with attorney fees under $\S 285$ of the Patent Act, parties in exceptional patent cases have come to rely on this practice. As a result, the questions presented by West Virginia regarding the Federal Circuit's authority to continue to grant such awards are particularly significant for these litigants. This Comment focuses on whether the Supreme Court's ruling in West Virginia effectively overrules this Federal Circuit practice, so that district courts in exceptional patent infringement cases may no longer award expert witness fees beyond the limits imposed by the Fees Act.

In holding that the term "attorney's fees" does not include expert witness fees, the Supreme Court in West Virginia underscored its increasingly rigorous requirement of "explicit statutory authority" for expert witness fee awards-as it has in many other areas of law. ${ }^{18}$ However, the Court's opinion in West Virginia did not carefully explore the relationship between this requirement and the award of expert fees under the district courts' inherent equity power. This Comment therefore analyzes the relationship between $\S 285$ and the district courts' equitable authority to award litigation expenses to prevailing parties. Section I discusses the American rule not to award litigation expenses absent explicit statutory authority and examines several federal statutes that authorize fee shifting. Section II explores the courts' equity power to shift

Inc. v Geo. A. Hormel \& Co., 723 F2d 1573, 1578 (Fed Cir 1983) (finding an award of nonattorney fee expenses was properly within the scope of $\S 285$ ).

1s 111 S Ct 1138 (1991).

${ }^{16} 42$ USC $\S 1988$ (1988) (in actions brought under the Civil Rights Act, "the court, in its discretion, may allow the prevailing party ... a reasonable attorney's fee as part of the costs").

$17111 \mathrm{~S} \mathrm{Ct}$ at 1148.

1s See, for example, Crawford Fitting Co. v J.T. Gibbons, Inc., 482 US 437, 444 (1987). 
litigation expenses and the limited circumstances under which a court may exercise its equitable discretion. Section III presents the evolving relationship between the Patent Act's attorney fee shifting provision and the courts' equity power, especially with respect to the Federal Circuit's treatment of this provision as authority to shift expert witness fees. This Section concludes that $\S 285$ codifies all of the courts' "bad faith" equitable fee shifting power and thereby authorizes courts to award expert witness fees. It addresses objections to this position and explores the significance of the Patent Act's legislative and judicial history in light of the Supreme Court's reasoning in West Virginia. Section IV outlines the policy considerations supporting expert witness fee shifting in exceptional patent cases. The Comment concludes that courts should still construe $\S 285$ to allow expert witness fee awards in exceptional patent cases and specifically that the Supreme Court's ruling in West Virginia does not overrule this Federal Circuit practice.

\section{Statutory Authority for Awarding Litigation Expenses: Judicial Deference to the Legislature}

Judicial reluctance to shift litigation fees in the absence of statutory authority dates back to the late $1700 \mathrm{~s}^{19}$ Early legislation, beginning with the Federal Judiciary Act of September 24, 1789, provided that federal courts were to follow the practice of their respective states in awarding litigation expenses. ${ }^{20}$ Many state legislatures either prohibited or limited these awards and, as the Supreme Court recently characterized this period, "the Judiciary itself would not create a general rule, independent of any statute, allowing awards of attorney's fees in federal courts."21 The federal courts tended to follow the American rule that parties should bear their own expenses. ${ }^{22}$ The policy behind this practice was, and con-

\footnotetext{
10 See Alyeska Pipeline Service Co. $v$ Wilderness Society, 421 US 240, 247-50; Rohm \& Haas, 736 F2d at 690 .

${ }^{20}$ See the Federal Judiciary Act of September 24, 1789, 1 Stat 73, §§ 9, 11-12, 20, 35; Act of September 29, 1789, 1 Stat 93, § 2, extended by the Act of May 26, 1790, 1 Stat 123, and again by the Act of February 18, 1791, 1 Stat 191, and repealed by the Act of May 8, 1792, I Stat 278, \& 8.

${ }^{21}$ Alyeska, 421 US at 249.

${ }^{22}$ Marek $v$ Chesny, 473 US 1, 8 (1985); Alyeska, 421 US at 247; Hall v Cole, 412 US 1, 4 (1973); Farmer v Arabian American Oil Co., 379 US 227, 235 (1964); Arcambel v Wiseman, 3 US (3 Dal) 306 (1796).
} 
tinues to be, "to avoid penalizing a party 'for merely defending or prosecuting a lawsuit." "2s

A. The Fees Act

In response to the inconsistent practice that developed across the federal courts, Congress standardized the costs and fees recoverable in federal litigation. ${ }^{24}$ By the Fees Act of February 26, 1853, Congress limited attorney fee awards and gave the district courts discretion to award a limited category of costs. ${ }^{25}$ The substance of this act eventually appeared in the United States Code in 1946 as 28 USC § $1920 . .^{26}$ Section 1920 includes witness fees among its allowable costs, but $\S 1821$ restricts these costs to $\$ 40$ for each day's attendance at trial. ${ }^{27}$ The Supreme Court has held that sections 1920 and 1821 limit the reimbursement of fees paid to expert witnesses unless a contract, statute, or exceptional circumstances provide otherwise. ${ }^{28}$

\section{B. Specific Provisions Under Selected Statutes for Attorney's Fees}

In addition to sections 1920 and 1821, Congress has included attorney and expert witness fee shifting provisions in statutes granting or protecting specific federal rights. These provisions pro-

23 Rohm \& Haas, 736 F2d at 690, quoting Fleischman Distilling Corp. v Maier Brewing Co., 386 US 714, 718 (1967).

24 See Cong Globe, 32d Cong, 2d Sess 583-84 (1853) (remarks of Senator Bradbury); HR Rep No 50, 32d Cong, 1st Sess 1-6 (1852).

${ }^{28} 10$ Stat 161 (1853), codified at Rev Stat $\S 823-57$ (1873-74). The Act provided that with respect to witness fees:

For each day's attendance in court, or before any officer pursuant to law, one dollar and fifty cents, and five cents per mile for travelling from his place of residence to said place of trial or hearing, and five cents per mile for returning. Id at 167.

${ }^{28} 62$ Stat 955 (1948). Today, the Fees Act provides that "[a] judge or clerk of any court of the United States may tax as costs the ... [f]ees and disbursements for printing and witnesses." 28 USC \& 1920 (1978).

2728 USC \& 1821 provides:

(a)(1) Except as otherwise provided by law, a witness in attendance at any court of the United States ... shall be paid the fees and allowances provided by this section. ...

(b) A witness shall be paid an attendance fee of $\$ 40$ per day for each day's attendance. A witness shall also be paid the attendance fee for the time necessarily occupied in going to and returning from the place of attendance at the beginning and end of such attendance or at any time during such attendance.

${ }^{28}$ West Virginia, 111 S Ct at 1140-41; Crawford, 482 US at 444; Alyeska, 421 US at 257-59. 
vide the only statutory authority for expert fee awards above $\$ 40$ per day and vary in specificity. Many, including the Patent Act's fee shifting provision, provide express authority for attorney fee awards; other more recent statutes also specifically provide for the recovery of expert witness fees. ${ }^{2 \theta}$

The Supreme Court has acknowledged that even those provisions providing only for attorney fee shifting "differ considerably among themselves." 30 The Court has explicitly distinguished between the attorney fee shifting provisions of the Patent Act and the Civil Rights Act. In patent litigation, "[t]he court in exceptional cases may award reasonable attorney fees to the prevailing party." 1 In contrast, under the Civil Rights Act "the court, in its discretion, may allow the prevailing party ... a reasonable attorney's fee as part of the costs." 32 The Supreme Court, in interpreting the Civil Rights Act, has held that "Congress intended that the award should be made to the successful plaintiff absent exceptional circumstances." 33

Thus, the Supreme Court has recognized that different standards apply to fee shifting under the Patent and Civil Rights Acts. These standards, resting on the distinctive wording of each act, led the Court to conclude that, "[u]nder this scheme of things, it is apparent that the circumstances under which attorneys' fees are to be awarded and the range of discretion of the courts in making those awards are matters for Congress to determine." ${ }^{34}$

\section{Fee Shifting In Equity}

Notwithstanding the requirement of express statutory authority for attorney and expert fee shifting, the district courts have long exercised their inherent equity power to award litigation expenses to the prevailing party in exceptional circumstances despite the absence of statutory authorization.

29 Westlaw searches for "expert witness fees" and "fees for expert witness!" uncovered 41 federal statutes that expressly shift expert witness fees in addition to attorney fees. See, for example, the Equal Access to Justice Act, 28 USC \$ 2412(d)(2)(A) (1988); the Consumer Product Safety Act, 15 USC \& 2060(c) (1988); the Clean Air Act, 42 USC § 7413(b) (1988); the Longshore and Harbor Worker's Compensation Act, 33 USC § 928(d) (1988). See generally West Virginia, $111 \mathrm{~S} \mathrm{Ct}$ at 1142 n 4 (listing statutes).

${ }^{30}$ Alyeska, 421 US at 261.

${ }^{31} 35$ USC $\$ 285$ (1988) (emphasis added).

${ }^{32}$ Civil Rights Attorney's Fees Awards Act of 1976, 42 USC $\S 1988$ (1988). See also Title II of the Civil Rights Act of 1964, 42 USC $\$ 2000 \mathrm{a}-3(\mathrm{~b})$ (1988).

${ }^{33}$ Alyeska, 421 US at 262.

${ }^{34}$ Id. 


\section{A. Background}

American courts generally have the equity jurisdiction that was vested in the English Court of Chancery, subject to modifications by Congress..$^{35}$ This equity power rested largely on the Chancellor's discretion to "act in accordance with the dictates of the judicial conscience," ${ }^{36}$ and included the power to give "as much of the entire expenses of the litigation of one of the parties as fair justice to the other party will permit . . .."37 The First Judiciary Act gave the federal courts jurisdiction over suits in equity. ${ }^{38}$ Following the merger of law and equity, all district courts acquired this equitable discretion unless restricted by statute..$^{39}$

The Supreme Court has recognized both this general equity power and, specifically, the "power of federal courts in equity suits to allow counsel fees and other expenses entailed by the litigation not included in the ordinary taxable costs recognized by statute."40 The Court has concluded that the "[a]llowance of such costs in appropriate situations is part of the historic equity jurisdiction of the federal courts,"41 and includes the power to shift expert witness fees. ${ }^{42}$ The Court has strictly limited these awards to "exceptional cases" involving "dominating reasons of justice."

Today the Court recognizes only a few exceptional cases, including those in which the losing party has acted "in bad faith, vexatiously, wantonly, or for oppressive reasons." 44 Thus, while equity gives courts discretion to shift a broad range of expenses, including expert witness fees, only a narrow category of circumstances will justify such equitable awards.

35 Sprague v Ticonic National Bank, 307 US 161, 164-65 (1939). See also 27 Am Jur 2d Equity $\$ \$ 5-6$ (1966), citing the Federal Judiciary Act of September 24, 1789, 1 Stat 73; Williamson v Berry, 49 US (8 How) 495, 535-56 (1850); Bodley v Taylor, 9 US (5 Cranch) 191, 222-23 (1809).

36 27 Am Jur 2d Equity § 9.

${ }^{37}$ Sprague, 307 US at 165.

3s 1 Stat $73, \S 11$.

39 See Crawford, 482 US at 448 (Marshall dissenting). See generally Sprague, 307 US at 164-65; 27 Am Jur 2d Equity §§ 4-6.

10 Sprague, 307 US at 164 .

41 Id.

42 West Virginia, $111 \mathrm{~S} \mathrm{Ct}$ at 1143-44. See also Welsch v Likins, 68 FRD 589, 596-97 (D Minn 1975).

43 Sprague, 307 US at 167.

« F.D. Rich Co., Inc. v United States, 417 US 116, 129 (1974). 
B. Relation of Equity to the Fees Act

Following the Fees Act of 1853, predecessor to 28 USC sections 1920 and 1821, the Supreme Court considered the Act's effect on both the types of litigation expenses allowed in equity and the circumstances justifying the district courts' power to award litigation costs beyond the amount specified by the statute. In Trustees $v$ Greenough, ${ }^{45}$ the Court found that the case presented an appropriate situation for granting litigation expenses in equity but expressed doubt about its continuing power to award these expenses beyond the limits of the Fees Act. ${ }^{46}$ The Court concluded that the Fees Act "may have its full effect without being construed to take away the power of a court of equity to permit counsel fees" where equitable requirements have been met. ${ }^{47}$ The Supreme Court later held that equitable fee shifting beyond the limits of the Fees Act applied to all litigation expenses, not just attorney fees, ${ }^{48}$ while continuing to emphasize that such fee shifting would only be available in "exceptional cases" or those involving "dominating reasons of justice."49

The Court has considered the appropriateness of the circumstances justifying equitable fee shifting on a case-by-case basis. For example, the Court has permitted cost recovery upon finding "obstinate noncompliance with the law or the use of the judicial process for purposes of harassment or delay in affording rights clearly owed." "5o It frequently justified such decisions on the grounds that the defendant's actions have forced the plaintiff to act as "private attorneys general." civil rights cases where plaintiffs were forced to incur substantial costs to secure constitutional rights. ${ }^{52}$ In addition, the Court has allowed equitable fee shifting where the losing party acted in bad faith. ${ }^{\text {s3 }}$

The Court's limited application of equitable fee shifting prevented equity from swallowing the Fees Act entirely. In a further

18105 US 527 (1881).

${ }^{48}$ Id at 535.

47 Id.

¿8 Sprague, 307 US 161.

49 Id at 167.

${ }^{50}$ Bradley $v$ School Board of The City of Richmond, 416 US 696, 706 (1974).

s1 Id at 708. See also Northcross $v$ Board of Education of Memphis City Schools, 412

US 427, 428 (1973); Newman v Piggie Park Enterprises, Inc., 390 US 400, 402 (1968).

${ }^{52}$ Bradley, 416 US at 719-20 \& n 27.

${ }^{53}$ See, for example, Hall v Cole, 412 US 1, 5 (1973); Universal Oil Products Co. $v$ Root Refining Co., 328 US 575, 580 (1946); F. D. Rich, 417 US at 129. 
effort to protect the Fees Act, the Supreme Court in 1975 imposed even stricter limits on the circumstances allowing equitable fee shifting. Acknowledging in Alyeska Pipeline Service $v$ Wilderness Society ${ }^{54}$ that the fee statutes have been construed to allow equitable fee shifting beyond statutory limits in certain cases, the Court restricted equitable fee awards to three situations: (1) "to permit the trustee of a fund or property, or a party preserving or recovering a fund for the benefit of others in addition to himself, to recover his costs"; (2) to allow recovery of fees for the willful disobedience of a court order; or (3) to allow recovery of fees "when the losing party has 'acted in bad faith, vexatiously, wantonly, or for oppressive reasons ...." "ळs Although the decision has been criticized for restricting the circumstances in which a district court could shift fees in equity to "immaterial exceptions," restrict the types of expenses traditionally shifted in equity.

These limitations on equitable fee shifting play an important role in shaping the district courts' continuing equitable authority to shift expenses, including expert fees, especially in light of the Supreme Court's holding in Crawford Fitting Co. $v$ J. T. Gibbons. ${ }^{57}$ One interpretation of Crawford might suggest that equity no longer allows expert witness fee shifting beyond the limits of the Fees Act. In Crawford, the Court held that "absent explicit statutory or contractual authorization for the taxation of the expenses of a litigant's [expert] witnesses as costs, federal courts are bound by the limitations set out in 28 USC $\S 1821$ and $\S 1920$."口8 Crawford reaffirmed Henkel v Chicago, St. Paul, Minneapolis \& Omaha $R y$. Co., ${ }^{39}$ decided fifty-five years earlier, in which the Court held that federal courts could not award expert witness fees in excess of the limit imposed by the Fees Act of $1853 .^{60}$ The Court decided Henkel before the merger of law and equity, and it did not consider whether equity would allow such an award.

54421 US 240 (1975).

ss Id at 257-59.

so Friedrich v City of Chicago, 888 F2d 511, 518 (7th Cir 1989), cert granted and judgment vacated by $111 \mathrm{~S}$ Ct 1383 (1991).

${ }^{87} 482$ US 437 (1987).

s8 482 US at 445 . Note that Crawford did not expressly rule that attorney fee shifting provisions do not provide the requisite authority. Although most federal courts of appeals have interpreted Crawford to disallow expert witness fee recovery as part of an attorney's fee award, see E. Richard Larson, Recent Developments in the Law of Attorneys' Fees, C517 ALI-ABA 711, 815 (1990), the Supreme Court did not expressly address this issue until it decided West Virginia.

so 284 US 444 (1932).

so Id at 446-47. 
While neither Crawford nor Henkel allowed the petitioner to shift expert witness fees in equity, neither opinion demonstrated appropriate exceptional circumstances that would warrant such equitable discretion. While the Court in Crawford rejected the petitioner's assertion that Henkel had neglected equitable fee shifting only because it was decided before the merger of law and equity, Henkel's decision comports entirely with the simple lack of equitable circumstances. Thus, the recovery of expert witness fees in "exceptional" cases does not conflict with Crawford's or Henkel's reasoning. Notably, the Court in Crawford repeatedly cited its decision in Alyeska with approval and again rejected the same assertion posited and rejected there, namely that "courts sitting in equity ha[ve] broad discretion to award fees not specified by statute."61 Explicitly relying on Alyeska's holding that this discretion does not extend beyond a few exceptional circumstances, Crawford denied that Congress extended any "roving authority" to the courts to allow litigation expenses "whenever the courts might deem them warranted."62

Thus, the Supreme Court did not deny that the district courts have equitable authority to shift expert witness fees beyond the limits of the Fees Act. Rather, the Court's failure to acknowledge equitable expert fee shifting in Crawford and Henkel demonstrates equity's limitation to certain exceptional circumstances that did not exist in those cases. Crawford and Henkel merely illustrate the limits on the appropriate circumstances for equitable fee shifting.

Just as the requirement for exceptional circumstances reconciles Crawford and Henkel with Alyeska's acknowledgement of equitable fee shifting, it also reconciles West Virginia's denial of expert witness fees under the Civil Rights Act with the Federal Circuit's award of these fees under $\S 285$ of the Patent Act. Like equity, but unlike the Civil Rights Act, $\S 285$ strictly limits the circumstances that warrant fee shifting. In fact, § 285's limitations on the circumstances permitting fee shifting are nearly identical to the "bad faith" prong of the equitable fee shifting standard imposed by Alyeska. This common restriction forms the basis of the strong relationship between equity and $\S 285$, and distinguishes $\S 285$ from the attorney fee shifting provision of the Civil Rights Act.

\footnotetext{
61 Crawford, 482 US at 443.

${ }^{62}$ Id at 444, quoting Alyeska, 421 US at 260.
} 
III. Congress's Intent to Codify Equity in § 285 AS JustificaTION FOR AWARDing EXPERT WitNESS Fees

The codification of equitable principles in $\S 285$ strongly suggests that Congress incorporated the authority to award all litigation expenses recoverable in equity. In particular, the parallel circumstances allowing fee shifting under equity's bad faith standard and $\S 285$ strengthen the assertion that $\S 285$ also parallels the types of fees awardable in equity. Section 285 , like its equity parallel, therefore includes the authority to shift expert witness fees.

\section{A. Identical Standards for "Exceptional Cases" in Equity and $\S 285$}

The judicial treatment of $\S 285$ demonstrate that the bad faith prong of the equitable circumstances outlined in Alyeska is identical to that adopted for the award of fees under $\S 285$. Courts have consistently held that the applicable standard for determining whether a case is "exceptional" under $\S 285$, with concomitant fee shifting, is "whether there is a showing of unfairness or bad faith in the conduct of the losing party, or any other equitable consideration of similar force which makes it grossly unfair that the winner of the lawsuit be left to bear the burden of his own counsel fees." 63

Using this narrow standard, the Federal Circuit has limited attorney and expert fee shifting under $\S 285$ to cases involving such circumstances as willful infringement, ${ }^{64}$ fraud in procuring the patent, ${ }^{66}$ misconduct during the suit, ${ }^{66}$ persistence with a suit knowing that the asserted patent is invalid, ${ }^{67}$ or " "unfairness, bad faith, or inequitable conduct' " on the part of a patentee asserting infringement. ${ }^{68}$ Furthermore, the court has consistently required the party

${ }_{63}$ Crown Machine and Tool Co. v KVP-Sutherland Paper Co., 297 F Supp 542, 577 (N D Cal 1968), aff'd, 409 F2d 1307 (9th Cir 1969). See also Codex Corp. v Milgo Electronic Corp., 541 F Supp 1198, 1201 (D Mass 1982); PPG Industries v Celanese Polymer Specialties, 658 F Supp 555, 558-59 (W D Ky 1987), rev'd on other grounds, 840 F2d 1565 (Fed Cir 1988); Campbell v Spectrum Automation Co., 601 F2d 246, 251 (6th Cir 1979).

${ }^{64}$ Rohm \& Haas, 736 F2d at 693, citing Rosemount, Inc. v Beckman Instruments Inc., 727 F2d 1540 (Fed Cir 1984) and Lam, Inc. v Johns-Mansville Corp., 718 F2d 1056 (Fed Cir 1983).

as Rohm \& Haas, 736 F2d at 693.

Bs Id.

e7 Id.

${ }^{88}$ Id, quoting Stevenson v Sears, Roebuck and Co., 713 F2d 705, 713 (Fed Cir 1983). 
requesting fee shifting under $\S 285$ to present strong evidence that the case is exceptional. ${ }^{69}$

The Federal Circuit has noted the strong similarity between $\S 285$ and the district courts' inherent equity power to shift costs in certain circumstances, though it has never explained its significance. In Rohm \& Haas v Crystal Chemical Co., ${ }^{70}$ the court cited $\S 285$ and its predecessor as examples of "statutory provisions [that] have been enacted so as to further equitable considerations . . . for the purpose of enabling a court to prevent gross injustice." When the Federal Circuit addressed the issue of expert witness fee shifting in Mathis, it based its award of expert fees squarely upon its inherent equity power as codified in $\S 285 .^{71}$

The Federal Circuit has not always cited the relationship between $\S 285$ and equitable principles to justify its awards of expert witness fees. In fact, the court's treatment of $\S 285$ has evolved since the court's inception in 1982 . In the early years of the court, it based its award of expert fees under $\S 285$ on its interpretation that attorney's fees "include those sums that the prevailing party incurs in the preparation for and performance of legal services related to the suit."72

The Supreme Court's perspective on this issue became significant when in West Virginia it rejected the original justification of expert witness fee awards as an element of attorney's fees. Before that ruling, the Federal Circuit had found it unnecessary to justify expert fee awards on equitable grounds. After West Virginia, however, the circuit court's reference to $\S 285$ 's equitable background remains the only viable justification for expert witness fee awards. If $\S 285$ is merely a shorthand codification of the courts' inherent equitable fee shifting power, as the Federal Circuit suggested in Rohm \& Haas, then this statutory power should include the authority to shift all fees awardable in equity, including expert witness fees.

98 CTS Corp. v Piher International Corp., 727 F2d 1550, 1564-65 (Fed Cir 1984) (attorney fees denied because opposing party's motions were neither exceptional nor in bad faith); Orthopedic Equipment Co. $v$ All Orthopedic Appliances, Inc., 707 F2d 1376, 1384 (Fed Cir 1983); Stickle $v$ Heublein, Inc., 716 F2d 1550, 1555 (Fed Cir 1983). See also Gary M. Ropski and Marc S. Cooperman, Damages in USA Intellectual Property Litigation, $72 \mathrm{~J}$ Pat Off Soc'y 181, 192-93 (1990); Ronald B. Coolley, Obtaining Attorney's Fees for Corporate Patent Counsel's Assistance in Litigation, 72 J Pat Off Soc'y 212, 214-15 (1990).

70736 F2d 688, 690 (Fed Cir 1984).

71857 F2d at 759.

${ }^{72}$ Central Soya, 723 F2d at 1578. See also Lam, 718 F2d at 1069. 
B. Objections to the Argument that Congress Intended §. 285 to Authorize Expert Fee Shifting

This reasoning presents several difficulties. If the courts have residual equity power to shift all litigation expenses in exceptional circumstances outside of any statutory authority; then $\S 285$, which simply provides statutory authority to award attorney's fees in these same "exceptional" cases, is redundant. Because the standard for $\S 285$ and equitable fee shifting are identical, a case in bad faith that triggers the award of attorney's fees under $\S 285$ should automatically trigger equitable shifting of expert fees. ${ }^{73}$ This redundancy suggests that awarding litigation expenses under $\S 285$ is unnecessary; on finding a case to be exceptional, the court could award these fees under its residual equity power.

The legislative and judicial background of $\S 285$ provides the crucial framework for understanding the necessary and distinct role that $\S 285$ serves in patent cases. In effect, Congress enacted $\S 285$ in response to the judiciary's removal of equitable fee shifting from patent litigation. Thus, Congress intended $\S 285$ to restore rather than to fortify equitable fee shifting, including the authority to shift expert witness fees, to exceptional patent cases.

1. Judicial and legislative background-no equitable fee shifting in patent cases.

The judicial background against which Congress enacted the fee shifting provision of the Patent Act differs remarkably from that of fee shifting statutes in other areas of the law. Prior to 1946, the damages recoverable by statute in patent infringement cases did not include attorney's fees, ${ }^{74}$ and the Supreme Court had held that the award of attorney's fees in equity was not available in patent cases. ${ }^{75}$

In Day $v$ Woodworth, ${ }^{76}$ decided two years before the Fees Act limited litigation fee awards, the Court stated that the patent laws authorized neither the court nor the jury to award litigation fees in

\footnotetext{
${ }^{33}$ The Fifth Circuit awarded both expert and attorney fees in equity in a patent infringement case. See Kinnear-Weed Corp. $v$ Humble Oil \& Refining Co., 441 F2d 631, 63637 (5th Cir 1971).

74 See the Patent Act of July 4, 1836, 5 Stat 117, $123 \S 14$.

${ }^{75}$ See Day $v$ Woodworth, 54 US (13 How) 363, 372-73 (1851); Teese $v$ Huntingdon, 64 US (23 How) 2, 8-9 (1859) (no expenses awarded because Patent Act of July 4, 1836 already provided for treble damages for bad faith); Philp v Nock, 84 US (17 Wall) 460, 462 (1873); Parks v Booth, 102 US 96, 107 (1880).

${ }^{76} 54$ US at 372.
} 
equity, even if "the defendant has not acted in good faith, or has been stubbornly litigious, or has caused unnecessary expense and trouble to the plaintiff." The Court reasoned that the patent laws already allowed the district courts to treble the actual damages where the defendant had acted in bad faith. ${ }^{77}$ Allowing an additional equitable award of counsel fees would inflict a double penalty on the defendant. ${ }^{78}$

Although Day was an action in trespass, and the above reasoning dicta, the Court subsequently held in a patent case, Teese $v$ Huntingdon, ${ }^{79}$ that even where the defendant acted in bad faith, "[c]ounsel fees are not a proper element for the consideration of the jury in the estimation of damages in actions for the infringement of a patent right." Thus, the Supreme Court effectively removed patent cases from the reach of equitable shifting of attorney's fees. Although it used the term "counsel fees" instead of "litigation expenses," the Court's strong reliance on Day and its interchangeable use of "counsel fees" and "litigation expenses" or "costs" throughout the opinions discussing equitable fee shifting suggests that Teese signalled a complete removal of equitable fee shifting from patent cases.

2. Congress's intent to restore equitable fee shifting in the Patent Act's attorney fee shifting provision.

Against this judicial background in 1946, Congress enacted a provision to allow recovery of attorney's fees in patent cases. The original attorney fee shifting provision of the Patent Act ${ }^{80}$ stated that a "court may in its discretion award reasonable attorney's fees to the prevailing party upon the entry of judgment on any patent case." ${ }^{81}$ This codification of an attorney fee shifting power was not redundant because Teese had established that district courts had no equitable discretion to award "counsel fees" prior to its enactment.

a) A literal approach. The use of the terms "counsel fees" and "attorney's fees" rather than "litigation expenses" in Teese and in $\S 70$ suggests another argument for the continued shifting

\footnotetext{
77 Id, referring to 5 Stat 123, now codified at 35 USC $\S 284$ (1988) ("the'court may increase the damages up to three times the amount found or assessed").

78 Id at 372-73.

78 64 US at $8-9$, citing Day, 54 US at 372 .

so 35 USC $\$ 70$ (1946).

Act of August 1, 1946, 60 Stat 778, codified at 35 USC $\S 70$ (1946).
} 
of expert fees in exceptional patent cases. The Supreme Court's use of the term "counsel fees" in Teese removed only equitable attorney fee shifting from patent cases and left other litigation fee shifting alone. The restoration of "attorney fee" shifting in $\S 70$ would then reflect a specific and exact reversal of the precedent set in Teese, restoring only equitable attorney fee shifting. By this reasoning, equitable expert fee shifting has always been and would still be allowed in patent cases, and remains unaffected by both Teese and $\S 285$.

While this interpretation leads to the same result posited by this Comment-courts may continue to award expert witness fees in exceptional patent cases even after West Virginia-this interpretation may be criticized as excessively literal. A broader reading of the term "attorney's fees" in both Teese and $\S 70$ seems to comport more closely with the likely intents of both the courts and Congress. Even so, under the literalist interpretations, courts may nevertheless award expert fees in their discretion beyond the limits of the Fees Act in the same circumstances warranting fee shifting under $\S 285$ and its predecessor, $\S 70$.

b) Congressional intent. The strongest evidence that Congress's original enactment of $\S 70$ did not reflect its equitable underpinnings arises from its failure to specify the limited circumstances in which Congress intended it to apply. Despite the liberal wording of $\S 70$, which allowed the court to award fees "in its discretion," Congress did not intend it as a broad grant of authority to award attorney's fees in all possible circumstances. Although the Patent Act's original grant of authority was not expressly limited to exceptional cases, the Senate Report stated:

It is not contemplated that the recovery of attorney's fees will become an ordinary thing in patent suits, but the discretion given the court in this respect, in addition to the present discretion to award triple damages, will discourage infringement of a patent by anyone thinking that all he would be required to pay if he loses the suit would be a royalty. The provision is made general so as to enable the court to prevent a gross injustice to an alleged infringer. ${ }^{82}$

${ }^{82}$ S Rep No 1503, 79th Cong, 2d Sess (1946) in 1946 USCCS 1386, 1387. Note that Congress intended attorney fees to bolster the already existing discretion to grant treble damages in bad faith cases. Congress thereby implicitly rejected the Supreme Court's reasoning in Day that an award of attorney fees, in addition to treble damages, would unfairly overpenalize the losing party. See Day, 54 US at 372 . 
Unfortunately, Congress was less clear in drafting the statute than it was in the accompanying reports and discussions. The legislative history suggests that Congress intended to limit the authority to grant litigation fees to special cases involving "gross injustice," a restriction embodying principles of equity. These same equitable principles historically included the authority to shift all litigation expenses, including expert witness fees, ${ }^{83}$ in limited circumstances. It seems likely, therefore, that Congress intended this statute to restore the courts' entire equitable fee shifting authority, not only the authority to shift attorney's fees.

Following the enactment of $\S 70$, courts recognized the provision's equitable underpinnings and demonstrated a willingness to follow Congress's underlying intent rather than a strict wording of the act. Instead of allowing fee shifting "upon the entry of judgment on any patent case," $" 84$ as the statute by its plain language suggested, the courts interpreted this provision to allow fee shifting "primarily upon findings of extraordinary circumstances." 85

Later, Congress approved the court's interpretation of the statute by codifying this reading. When it revised this provision in the Patent Act of 1952, Congress explicitly required the case to be "exceptional" to comply with "the intention of the present statute as shown by its legislative history and as interpreted by the courts." 86 The exceptional cases requirement in $\S 285$ provides strong evidence that Congress in 1952 recognized its equitable background and intended the provision more clearly to codify equitable principles.

The context of the 1952 revision supports the claim that Congress intended the statute to allow fee shifting only in cases in which equitable fee shifting would be justified. In contrast, Congress refrained from clarifying the statute's ambiguity regarding the types of fees authorized to match those in equity. Until West Virginia, such clarification was unnecessary. The Federal Circuit, recognizing the provision's equitable characteristics, interpreted it

\footnotetext{
${ }^{83}$ See Friedrich, 888 F2d at 518; West Virginia, 111 S Ct at 1143-44.

35 USC $\$ 70$ (1946).

${ }^{85}$ Rohm \& Haas, 736 F2d at 691. As the Ninth Circuit explained:

The exercise of discretion in favor of such an allowance should be bottomed upon a finding of unfairness or bad faith in the conduct of the losing party, or some other equitable consideration of similar force, which makes it grossly unjust that the winner of the particular law suit be left to bear the burden of his own counsel fees which the prevailing litigants normally bear.
}

Park-In Theatres v Perkins, 190 F2d 137, 142 (9th Cir 1951).

${ }^{86} \mathrm{~S}$ Rep No 1979, 82d Cong, 2d Sess (1952), in 1952 USCCAN 2394, 2423. 
to authorize all litigation expenses awardable in equity, including expert witness fees. Further statutory modification will remain unnecessary if the district courts are permitted to continue their present interpretation of legislative intent.

3. Congress's silence with respect to expert witness fees in $\S 285$.

Before Congress enacted the Patent Act's fee shifting provision, the Supreme Court had removed patent cases from the reach of equitable fee shifting. Through $\S 285$, Congress restored this fee shifting authority to patent cases. However, Congress's silence with respect to expert witness fees in $\S 285$ might suggest that Congress intended to exclude expert witness fees from its restoration of the courts' equitable fee shifting power.

West Virginia made clear that the Supreme Court will rarely read into a statute what Congress has omitted. As the Court stated:

[T] he purpose of a statute includes not only what it sets out to change, but also what it resolves to leave alone. The best evidence of that purpose is the statutory text adopted by both Houses of Congress and submitted to the President. . . . "[W]here, as here, the statute's language is plain, 'the sole function of the court is to enforce it according to its terms." "87

Part of the Supreme Court's analysis in West Virginia addressed the statutory usage of the terms "attorney's fees" and "expert witness fees" just prior to 1976, when Congress enacted the civil rights statute at issue in that case. In particular, Congress passed the Civil Rights Act in the years following the enactment of several other laws that specifically provided for the award of expert fees, separate from attorney's fees. ${ }^{88}$ The Court concluded that "Congress could easily have shifted 'attorney's fees and expert witness fees,' or 'reasonable litigation expenses,' as it did in contemporaneous statutes; it chose instead to enact more restrictive language, and we are bound by that restriction." 89

Yet, the meaning of "attorney's fees" in 1946, the year Congress enacted the fee shifting provision of the Patent Act, differed considerably from its use in 1976. In 1946, Congress had not yet

${ }^{87}$ West Virginia, $111 \mathrm{~S}$ Ct at 1147, quoting United States $v$ Ron Pair Enterprises, 489 US 235, 241 (1989) (citations omitted).

8 Id at 1142 .

89 Id at 1147. 
demonstrated a distinction between attorney and expert witness fees under specific statutes outside the Fees Act. The few acts that provided costs to the prevailing party specified attorney's fees and did not list expert fees separately..$^{90}$ Thus, to the extent that West Virginia turned on Congress's demonstrated recognition of expert witness fees as an expense separate from attorney's fees in 1976, the Court's conclusions are largely inapplicable to $\$ .285$.

Congress's increasingly frequent use of the term "expert witness fees" in the past twenty-five years correlates with the judiciary's increasing use and recognition of expert testimony. Given the current importance of expert witnesses to patent litigation, ${ }^{91}$ Congress's failure to consider including the term "expert witness fees" in a statute enacted today would be determinative. But when Congress enacted $\S 285$ in 1946, expert witness testimony played a much smaller role in litigation, even in technical and scientific cases, and expert witness fees did not approach their current magnitude. ${ }^{92}$ Given the limited use of experts in the 1940s, it is not suprising that Congress did not separately acknowledge expert witness fees in its drafting of $\S 285$, but rather intended that the term "attorney's fees" encompass these and all other necessary litigation fees.

4. Distinction from the argument rejected in West Virginia.

The final and most serious objection to the proposal that Congress intended $\S 285$ to permit the shifting of all fees authorized in equity is that the Supreme Court rejected similar reasoning by the Seventh Circuit in Friedrich. The Supreme Court vacated Friedrich, which allowed expert witness fee shifting under the attorney fee shifting provision of the Civil Rights Act, in light of its ruling in West Virginia. In Friedrich, Judge Posner of the Seventh Circuit reasoned that Congress used " 'reasonable attorney's fee' as a shorthand expression for such fees and other expenses as the district court might in the exercise of its equitable discretion reasona-

so See, for example, the Interstate Commerce Act of 1887 § 24 Stat 379, 382; Clayton Act of $1914 \S 4$, 38 Stat 730, 731, codified at 15 USC $\S 15$ (1988); Copyright Act $\S 40$, 35 Stat 1075,1084 , codified at 17 USC $\$ 40$ (1946).

${ }^{91}$ Conley, 15 AIPLA at 386 (cited in note 1) (“... in almost every [patent]. case expert opinions will be necessary").

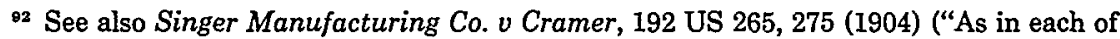
the patents in question it is apparent from the face of the instrument that extrinsic evidence is not needed to explain the terms of art therein, or to apply the descriptions to the subject matter ...."). For a contemporary opinion about the use of experts in the 1940s, see Leon R. Yankewich, On the Use of Experts in Patent Cases, 22 J Pat Off Soc'y 639 (1940). 
bly believe should be reimbursed to the prevailing party."93 The Supreme Court, however, rejected the assertion that the Civil Rights Act codified equitable power to shift expert fees. ${ }^{94}$

The Supreme Court also rejected a related argument offered by the plaintiff in West Virginia. The plaintiff argued that "attorney's fees" in $\S 1988$ of the Civil Rights Act should include expert witness fees because Congress enacted this provision to restore the broader equitable fee shifting power that existed before the Supreme Court's severe restrictions in Alyeska. In particular, Alyeska had rejected the "private attorneys general" doctrine, which had allowed equitable fee shifting in situations especially common in civil rights cases. ${ }^{95}$ The plaintiff in West Virginia argued "that $\S 1988$ was intended to restore the pre-Alyeska regime-and since expert fees were shifted then, they should be shifted now."96

The Court rejected this argument with respect to the Civil Rights Act. Conceding that the legislative history of $\S 1988$ "suggest[s] that at least some members of Congress viewed it as a response to Alyeska," the Court wrote that "[i]t is a considerable step, however, from this proposition to the conclusion ... that $\S$ 1988 should be read as a reversal of Alyeska in all respects." position that $\S 1988$ restores pre-Alyeska equity power in civil rights cases is similar in many respects to the proposal that the Patent Act's fee shifting provision, $\S 285$, restores courts' equity power to shift litigation expenses in patent cases, as it existed before Day and Teese.

Nevertheless, fundamental differences in the evolving relationships between equity and the Patent and Civil Rights Acts distinguish the argument here from the arguments advanced in Friedrich and West Virginia. In both patent and civil rights cases, equity originally allowed courts relatively broad discretion to shift attorney and expert fees in a variety of circumstances..$^{98}$ Day and Teese directly removed patent cases from the reach of equity..$^{99}$ Alyeska limited the circumstances justifying equitable fee shifting in all areas of the law, including civil rights, to three exceptional circumstances discussed in Section II.B.

9s 888 F2d at 518.

94 $111 \mathrm{~S} \mathrm{Ct}$ 1383, vacating and remanding for reconsideration in light of West Virginia, 111 S Ct 1138.

9s See text accompanying notes 51-52.

$98111 \mathrm{~S} \mathrm{Ct}$ at 1146.

92 Id.

98 See Section II.A.

92 See text accompanying notes 76-79. 
Although equitable fee shifting still applies to exceptional civil rights cases, Alyeska had severely limited the circumstances under which the courts could exercise this authority. In response to Alyeska, and to restore some of the broader equitable discretion that had existed before 1975, Congress enacted the fee shifting provision of the Civil Rights Act to allow courts to shift attorney's fees in their discretion. In a Senate Committee Report, Congress stated that "[ $t]$ his bill creates no startling new remedy-it only meets the technical requirements that the Supreme Court has laid down if the Federal courts are to continue the practice of awarding attorneys' fees which had been going on for years prior to the Court's [Alyeska] decision."100 In Friedrich, the Seventh Circuit argued that "reasonable attorney's fees" was shorthand for the fees allowed in equity before Alyeska, which included expert witness fees: "The term [reasonable attorney's fees] is the label for a power first asserted, then withheld, and finally restored; it is not an exhaustive description of the power."101

The Supreme Court rejected this assertion that the Civil Rights Act restored full equitable fee shifting because, "[b]y its plain language and as unanimously construed in the courts, § 1988 is both broader and narrower than the pre-Alyeska regime." ${ }^{102}$ It is broader because equitable fee shifting even before Alyeska was restricted to particular circumstances, such as those defining the "private attorneys general" doctrine. In other words, equity had not permitted fee shifting in the court's discretion absent these circumstances. By allowing fee shifting in the courts' discretion, $\S 1988$ "restored" a power much broader than that which had originally existed.

Section 1988, the Court explained, was in other respects narrower than the pre-Alyeska regime. Before 1975, broader equitable fee shifting had existed in almost all legal areas. Alyeska had limited equity's reach in these areas, yet the attorney fee shifting provision of the Civil Rights Act applied only to civil rights cases. It did not restore the broader pre-Alyeska fee shifting regime to all legal issues, but only to civil rights cases. ${ }^{103}$ Thus, despite Congress's apparent intentions, $\S 1988$ created a new equitable fee shifting system that did not mirror the system that had existed

$100 \mathrm{~S}$ Rep No 94-1011, 94th Cong, 2d Sess 6 (1976), in 1976 USCCAN 5908, 5913. See also Friedrich, 888 F2d at 518.

$101888 \mathrm{~F} 2 \mathrm{~d}$ at 518.

102 West Virginia, 111 S Ct at 1146.

103 Id. 
before Alyeska. Rather, with respect to the narrow civil rights area, $\S 1988$ created a broader fee shifting authority than that previously justified in equity. As the Court stated, "[s]ince it is clear that, in many respects, $\S 1988$ was not meant to return us precisely to the pre-Alyeska regime, the objective of achieving such a return is no reason to depart from the normal import of the text."104

The objections that led the Court to reject the equitable fee shifting argument in West Virginia do not apply to the Patent Act for two reasons. First, the Patent Act did not restore a broader authority than equity originally had allowed. Congress restricted the Patent Act's attorney fee shifting provision to "exceptional cases" to reflect its intent that the provision mirror equitable fee shifting. Rather than attempting to fortify equity's existing scope by eliminating its restrictive standard, as it did with the Civil Rights Act, Congress enacted $\S 285$ of the Patent Act to reestablish equitable fee shifting, with the concomitant limitations, in an area where courts had said there was no equitable fee shifting at all.105 Moreover, unlike the civil rights context, courts have interpreted and applied $\S 285$ to allow fee shifting only where it would be allowed in equity.

Second, the provision was no narrower than the situation it attempted to restore. The Civil Rights Act had too narrowly responded to Alyeska, a broad case limiting equity in all legal areas, but the Patent Act responded to cases that were themselves limited to patents. Just as Day and Teese had removed only patent cases from equity's reach, so the Patent Act restored equitable fee shifting only to patent cases. In this respect $\S 285$ responded directly and precisely to the judiciary's removal of patent cases from equity's reach, while accepting equity's restrictions. Section 1988 did not.

West Virginia's rejection of the equitable fee shifting argument, though understandable in the Civil Rights Act's context, finds no support in the context of the Patent Act. Section 285's incorporation of equitable fee shifting principles is supported by its legislative history, its restriction to "exceptional cases," the admitted purpose of its 1952 revision to better reflect the provision's intent, and the use of the term "attorney's fees" in the context of equitable fee shifting at the time of its drafting. These factors together support the proposition that Congress intended $\S 285$ to re-

\footnotetext{
104 Id.

${ }^{105}$ See text accompanying notes 76-79.
} 
store all equitable fee shifting to patent cases and implicitly included the authority to shift expert witness fees.

\section{Policy Considerations Supporting Expert Fee Shifting in Exceptional Patent Cases}

Policy considerations strengthen the conclusion that courts should continue to construe $\S 285$ to shift expert witness fees along with attorney's fees in exceptional patent cases. Commentators have recognized that the allocation of litigation costs may affect the behavior of parties in resolving disputes. ${ }^{106} \mathrm{~A}$ brief economic analysis will illustrate that expert witness fee shifting in exceptional patent cases helps to discourage frivolous, bad faith lawsuits.

A. Discouraging Bad Faith Patent Suits Through Expert Witness Fee Shifting

By shifting expert witness fees under $\S 285$, courts achieve two distinct policy goals: they deter bad faith patent suits and encourage otherwise reluctant plaintiffs to bring valid claims. This is because, in general, the allocation of litigation expenses, such as expert witness fees, affects the plaintiff's decision to assert a legal claim. ${ }^{107}$ Plaintiffs assert legal claims when they expect their recovery to exceed their costs. ${ }^{108}$ The higher the expected costs of losing relative to the expected judgment, the less likely the plaintiff is to bring suit.

A fee shifting provision like $\S 285$ effectively discourages bad faith lawsuits by increasing the expected costs involved in such suits. The spiteful plaintiff, filing a suit designed more to harass opponents that to secure a just reward, will find his expected costs higher in a system of fee shifting because he must anticipate the risk of paying his opponent's legal or expert fees in addition to his own. This decreases the plaintiff's expected judgment relative to

106 This discussion is based largely on Robert D. Cooter and Daniel L. Rubinfeld, Economic Analysis of Legal Disputes and Their Resolution, $27 \mathrm{~J}$ Econ Lit 1067 (1989) and Steven Shavell, Suit, Settlement, and Trial: A Theoretical Analysis Under Alternative Methods for the Allocation of Legal Costs, $11 \mathrm{~J}$ Legal Stud 55 (1982). These articles examine the effect on dispute resolution of various allocations of litigation costs as a general package of expenses, without distinguishing between different types of expenses or areas of the law. Shavell notes, "conclusions can be drawn in particular areas of litigation." Shavell, $11 \mathrm{~J}$ Legal Stud at 71.

${ }^{107}$ Shavell, $11 \mathrm{~J}$ Legal Stud at 56.

108 More precisely, the plaintiff's estimated judgment discounted by his probability of winning must be greater than his anticipated legal costs plus the anticipated shiftable legal costs of his opponent, discounted by his probability of losing. See id at 57-60. 
his expected costs and makes the plaintiff less likely to bring suit. ${ }^{109}$

Conversely, where the plaintiff believes she has a strong case, the frequency of suits will be greater under a system of litigation fee shifting than under a system where parties bear their own costs. ${ }^{110}$ This is true because the optimistic plaintiff anticipates that her legal costs may be shifted to her losing opponent, thereby decreasing the plaintiff's expected costs relative to her expected judgment. ${ }^{111}$ In other words, a patent holder who is optimistic about her claim will be more likely to bring an infringement suit against a competitor if she anticipates that her competitor will pay her expert witness fees than if the patent holder knows that, win or lose, she is certain to pay the high cost of her own experts.

Of course, some incentive problems may arise under a fee shifting regime. For example, advocates of the American rule often justify not shifting fees by observing that shifting expenses discourages the litigation of doubtful, yet potentially meritorious, claims by penalizing the losing party. ${ }^{112}$ Where the plaintiff is not optimistic about winning, the frequency of suits will be greater under a system where parties bear their own costs than under one where the loser pays the winner's expenses. This occurs because the plaintiff's litigation costs are constant in the first case, with the plaintiff paying only his own expert witness fees, regardless of the suit's outcome; but in a system of fee shifting, the pessimistic plaintiff anticipates paying his opponent's expert fees in addition to his own. The prospect of paying an opponent's expert fees may discourage a plaintiff with a doubtful, but valid, patent infringement claim from bringing suit against a competitor.

There are two reasons why this argument does not undercut fee shifting in all cases. First, the recent litigation explosion calls this argument into question. Discouraging some suits may now be advantageous. Second, a fee shifting provision like $\S 285$ avoids the deterrence of valid claimants, because it applies only in exceptional cases. Hence, it aims to discourage only those pessimistic parties who assert claims or defenses in bad faith. ${ }^{113}$

109 Id at $59-60$ \& $\mathrm{n} 19$.

110 Id at 59.

111 Id.

112 Alan M. Ahart, Attorneys' Fees: The Patent Experience, 57 J Pat Off Soc'y 608, 609 (1975); Note, Attorney's Fees as an Element of Damages, 15 U Cin L Rev 313, 315 \& n 10 (1941). See also Charles T. McCormick, Counsel Fees and Other Expenses of Litigation as an Element of Damages, 15 Minn L Rev 619, 638-42 (1931).

${ }^{113}$ Ahart, $57 \mathrm{~J}$ Pat Off Soc'y at 611-12 (cited in note 112). 
Ultimately, the benefits of fee shifting depend on the social desirability of encouraging or discouraging litigation in different contexts. ${ }^{114}$ In the context of patent litigation, Congress and the courts have long accepted that awarding attorney's fees under $\S 285$ strikes the proper balance of interests. Although the marginal effects of shifting expert fees in addition to attorney's fees may not coincide precisely with the original effects of shifting only attorney's fees, the incentive would be the same.

\section{B. Fairness}

The restriction of fee shifting to bad faith cases effects a second normative policy consideration: fairness. Litigation fee shifting is often justified by the principle that a prevailing party should not have to bear the "loss" of his legal costs. ${ }^{115}$ In other words, a patent holder who wins an infringement suit against a competitor should not have to pay the expenses of proving infringement. This presumes that the prevailing party advances the "morally superior" position and that the losing party is somehow "blameworthy." ${ }^{116}$ It seems unfair to penalize the losing party for merely defending himself or asserting a tenable but unsuccessful claim. Fee shifting may thereby discourage parties from asserting doubtful claims and defenses that courts would later find to have merit.

The Patent Act's attorney fee shifting provision overcomes this criticism by applying only to "exceptional" cases. It does not reach parties with fair and justifiable claims. The.policy behind the provision is itself based in equity and in preventing injustice to the prevailing party. ${ }^{117}$ Thus, just as a fairness consideration supports attorney fee shifting to bad faith litigants, it also supports shifting all other litigation expenses, including expert witness fees.

\section{Administrative Costs}

Discouraging bad faith patent litigation through expert witness fee shifting may outweigh its administrative costs. If such fee shifting in fact prevents frivolous patent litigation, the time saved by the courts through fewer lawsuits will compensate for the lengthening of those remaining trials that require an evaluation of the reasonableness of the prevailing party's fees. In addition, Con-

\footnotetext{
114 Shavell, $11 \mathrm{~J}$ Legal Stud at 71 (cited in note 106).

115 Id at 72.

116 Id.

${ }^{117}$ See Rohm \& Haas, 736 F2d at 692; Codex, 541 F Supp at 1201.
} 
gress has noted a further administrative advantage of expert witness fee shifting: "[u]nless successful plaintiffs can recover reasonable expert witness fees, their attorneys may be forced to perform pre-trial tasks that are more inexpensively and efficiently performed by experts in order to permit a recovery of costs." 118

Congress recently demonstrated the persuasiveness of policy considerations supporting expert witness fee shifting. Based in part on the policy implications outlined above, along with other policies unique to the civil rights area, in 1991, Congress amended the attorney fee shifting provision of the Civil Rights Act. ${ }^{119}$ This provision now allows prevailing parties to recover "a reasonable attorney's fee (including expert witness fees)."120 The House Report explains that the amendment "express[es] Congress's intention to conform Title VII to the rule announced in the Supreme Court's decision in Crawford Fitting Co. v J.T. Gibbons, Inc. and West Virginia University Hospital Inc. v Casey."121

\section{Conclusion}

While Congress, following its own lead with respect to the Civil Rights Act, could amend 35 USC $\S 285$ to allow explicitly for the recovery of expert witness fees in exceptional patent infringement cases, such an amendment is unnecessary. The Federal Circuit's current application of $\S 285$ to allow expert witness fee awards is entirely consistent with the existing provision's purpose of incorporating equitable fee shifting principles. This equitable power, as expressed by the Supreme Court, includes the authority to shift all litigation expenses, including expert witness fees, where the losing party has acted in bad faith. Section 285 , in its language and its application, allows fee shifting only where such an award would be justified in equity. Congress enacted it to restore equitable fee shifting to patent cases, rather than to supplement an already existing equity power. Consequently, this position overcomes the objections suggested by West Virginia. In effect, West Virginia does not overrule the Federal Circuit's practice of awarding expert witness fees to prevailing parties in exceptional patent cases, and the district courts should continue to award expert witness fees under $\S 285$.

11 HR Rep No 102-40(I), 102d Cong, 1st Sess 79 (1991), in 1991 USCCAN 549, 617, citing Friedrich, 888 F2d at 514.

${ }_{210}$ Title VII $\S 706(\mathrm{k})$, codified at 42 USC $\S 2000 \mathrm{e}-5(\mathrm{k})$ (1988).

${ }_{120}$ Civil Rights Act of 1991, Pub L No 102-166 § 113, 105 Stat 1071, 1079 (1991).

${ }^{121}$ HR Rep No 102-40(I) at 78-79 (cited in note 118). 
